\title{
PEMAHAMAN MAHASISWA FAKULTAS SYARI'AH DAN HUKUM UIN SUSKA RIAU TERHADAP KESESUAIAN KONSEP SYARIAH PADA BANK BRI SYARI'AH
}

\author{
Rozi Andrini \\ Universitas Islam Negeri Sultan Syarif Kasim Riau \\ Email : andrinirozi@gmail.com
}

\begin{abstract}
This paper discusses the understanding of the students of the Sharia Faculty and the Law of UIN Suska Riau on the suitability of the Islamic concept at the Sharia BRI Bank. This study is important to see the extent to which students' understanding of the suitability of the concept of sharia in the Sharia Bank. Basically, the Faculty of Sharia and Law students understand that the Sharia Bank is a bank whose operations are in accordance with the sharia concept or a concept that is justified in Islam. This understanding is obtained through campus learning. So that students' understanding of the concept of shari'ah in shari'ah banks can be a benchmark for making decisions to use the services of shari'ah banks. Ideally students who understand the concept of shari'ah will use the services of the shari'ah bank.
\end{abstract}

Keywords: Understanding, Sharia Concept, Sharia Bank.

\begin{abstract}
Abstrak
Tulisan ini membahas tentang pemahaman mahasiswa Fakultas Syari'ah dan Hukum UIN Suska Riau terhadap kesesuaian konsep syariah pada Bank BRI Syari'ah. Kajian ini penting untuk melihat sejauh mana pemahaman mahasiswa tentang kesesuaian konsep syariah pada Bank Syari'ah. Pada dasarnya mahasiswa Fakultas Syari'ah dan Hukum memahami bahwa Bank Syari'ah adalah bank yang operasionalnya sesuai dengan konsep syariah atau konsep yang dibenarkan didalam Islam. Pemahaman ini diperoleh melalui pembelajaran dikampus. Sehingga pemahaman mahasiswa terhadap konsep syari'ah pada bank syari'ah ini dapat menjadi tolak ukur mengambil keputusan untuk menggunakan jasa bank syari'ah. Idealnya mahasiswa yang memahami konsep syari'ah akan menggunakan jasa bank syari'ah tersebut.
\end{abstract}

Kata Kunci : Pemahaman, Konsep Syari'ah, Bank Syari’ah. 


\section{PENDAHULUAN}

Perkembangan dunia usaha dalam berbagai jenis industri, seakanakan tidak pernah berhenti karena bergeraknya zaman. Demikian juga dengan perkembangan industri perbankan. Dengan bergeraknya zaman dan adanya kebutuhan serta masukan dari masyarakat luas, perbankan yang ada saat ini banyak mengalami peningkatan yang cukup signifikan. Perkembangan ini diwujudkan dalam bentuk yang bervariasi baik dari segi inovasi produk, prinsip, sistem operasionalnya serta pergeseran paradigma. ${ }^{1}$

Sistem perbankan yang digunakan di Indonesia adalah dual banking system atau sistem perbankan ganda, dimana beroperasi dua jenis bank, yaitu Bank Konvensional dan Bank Syari'ah. Kemunculan Bank Syari'ah seiring dengan upaya gencar yang dilakukan oleh para pakar Islam dalam mendukung ekonomi Islam yang diyakini akan mampu mengganti dan memperbaiki sistem ekonomi konvensional yang berbasis pada bunga. Hal ini berbeda dengan konsep dan filosofi dengan Bank Konvensional yang menerapkan sistem bunga, Bank Syari'ah melarang penerapan bunga dalam semua transaksi perbankan karena termasuk kategori riba. Dalil yang melarang sistem riba terdapat dalam alqur'an surat al-Baqarah: 275.

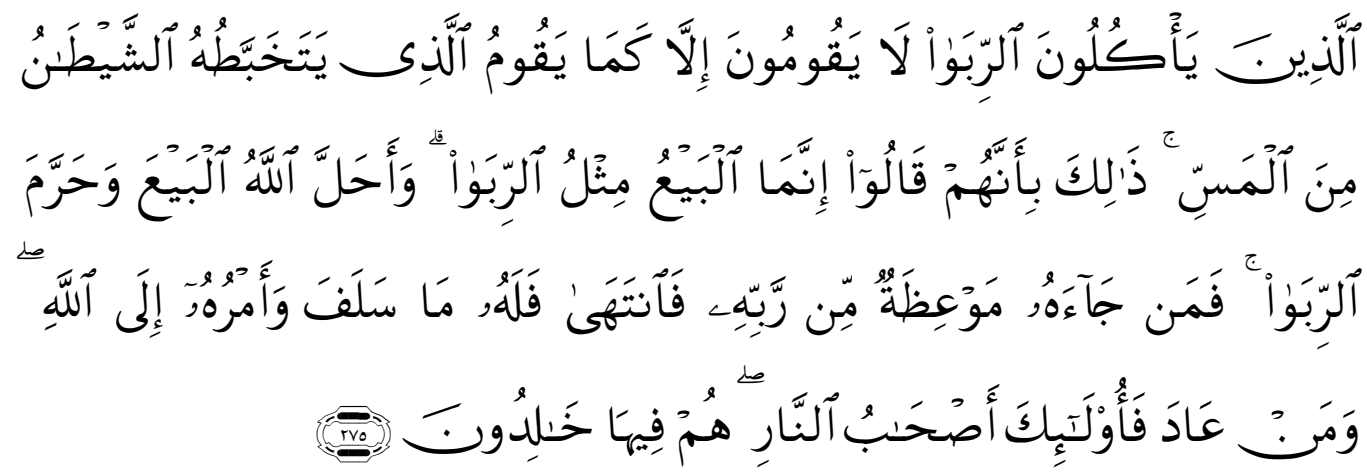

Artinya : "Orang-orang yang Makan (mengambil) riba tidak dapat berdiri melainkan seperti berdirinya orang yang kemasukan syaitan lantaran (tekanan) penyakit gila. Keadaan mereka yang demikian itu, adalah disebabkan mereka berkata (berpendapat), Sesungguhnya jual beli itu sama dengan riba, Padahal Allah telah menghalalkan jual beli dan mengharamkan riba. orangorang yang telah sampai kepadanya larangan dari Tuhannya, lalu terus berhenti (dari mengambil riba), Maka baginya apa yang telah diambilnya dahulu (sebelum datang larangan); dan

${ }^{1}$ http://library.walisongo.ac.id/digilib/gdl.php?mod=browse\&op=read\&id=jtptiain-gdlrifaatulma-4923, akses 25 Agustus 2015. 
urusannya (terserah) kepada Allah. orang yang kembali (mengambil riba), Maka orang itu adalah penghuni-penghuni neraka; mereka kekal di dalamnya."2

Bank Syari'ah adalah bank yang dalam aktivitasnya; baik dalam penghimpunan dana maupun dalam rangka penyaluran dananya memberikan dan mengenakan imbalan atas dasar prinsip syari' ${ }^{3}{ }^{3}$ dan menurut jenisnya terdiri atas bank umum syari'ah dan bank pembiayaan rakyat syari'ah. Prinsip syari'ah adalah prinsip hukum Islam dalam kegiatan perbankan berdasarkan fatwa yang dikeluarkan oleh lembaga yang memiliki kewenangan dalam penetapan fatwa di bidang syari'ah.

Berdasarkan data statistik perbankan syari'ah yang dikeluarkan oleh Otoritas Jasa Keuangan (OJK), per Juni tahun 2015 total aset perbankan syari'ah sebesar Rp. 272,389 miliar. Jumlah dan jaringan kantor perbankan syari'ah juga mengalami perkembangan, dimana pada tahun 1992-1998 hanya ada 1 unit Bank Syari'ah, maka pada tahun 2015, jumlah Bank Syari'ah di Indonesia telah bertambah menjadi 34 unit, yang terdiri dari 12 Bank Umum Syariah dan 22 Unit Usaha Syari'ah. ${ }^{4}$

Perkembangan BUS yang sangat signifikan tersebut memang dinilai sebagai prestasi yang cukup baik, di samping itu kenaikan asset BUS dari tahun ke tahun juga sangat menggembirakan. Akan tetapi perkembangan ini semestinya juga didukung oleh cerminan operasional BUS yang memegang teguh prinsip-prinsip syariah Islam. Hal ini tidak dapat dipungkiri, karena pendirian bank syariah merupakan suatu indikasi akan kemudharatan sistem bunga atau riba yang diharamkan dalam Islam dan secara tegas dalam fatwa MUI (16-12-2003) telah mengukuhkan tentang haramnya bunga pada Januari 2004. Keluarnya beberapa fatwa MUI tentang ekonomi syariah dan UU No. 21 tahun 2008 tentang bank syariah, lebih mengukuhkan eksistensi perbankan syariah di tengah proses pertumbuhan kegiatan usaha perbankan syariah di seluruh nusantara. Sehingga perbankan syariah yang memiliki layanan berbasis syariah mampu menambah kepercayaan masyarakat.

Semakin berkembangnya kepercayaan masyarakat, maka tentunya sangat diharapkan masyarakat mempunyai pengetahuan dan pemahaman tentang bank syariah yang lebih baik lagi. Hal tersebut diperlukan karena sebagaimana diketahui jumlah penduduk yang mayoritas beragama Islam seharusnya bisa mendongkrak pertumbuhan bank syariah ini ke depannya

\footnotetext{
${ }^{2}$ QS. Surah Al-Baqarah dalam Software Al-Qur'an Digital.

${ }^{3}$ Ahmad Rodoni dan Abdul Hamid, Lembaga Keuangan Syariah, (Jakarta: Zikrul Hakim, 2008), Cet. I, Hal. 14.

${ }^{4}$ Otoritas Jasa Keuangan, "Statistik Perbankan Indonesia", dalam www.ojk.go.id di akses 25 Agustus 2015.
} 
semakin lebih baik. Namun, pada kenyataannya berdasarkan penelitian Mahamad dan Tahir (2010) menyebutkan bahwa masyarakat masih banyak yang memilih bank konvensional. Permasalahan tersebut diidentifikasi dalam cetak biru Pengembangan Perbankan Syariah Indonesia Bank Indonesia (2002) sebagai hal-hal penting yang harus diperhatikan dalam upaya mendorong pertumbuhan industri perbankan syariah.

Peningkatan pertumbuhan jumlah asset dan jumlah jaringan Bank Syari'ah Di Indonesia juga terus dilakukan dengan berbagai cara, salah satu upaya Bank Syari'ah dalam mengembangkan usahanya adalah dengan menjalin kerjasama dengan berbagai lembaga pendidikan di Indonesia. Seperti menjalin kerjasama dengan Universitas-universitas Islam yang ada di Indonesia. Bagi Bank Syari'ah kerjasama tersebut sangat penting karena selain bertujuan untuk meningkatkan profit perusahaan juga memperluas jaringan kerja. Tak terkecuali oleh bank-bank syari'ah yang ada di Kota Pekanbaru. Universitas Islam Negeri Sultan Syarif Kasim Riau adalah salah satu lembaga pendidikan yang menjalin kerjasama dengan bank-bank syari'ah yang ada di kota Pekanbaru.

Menurut Akhmad Mujahidin dalam Ekonomi Islam 2, peran yang bisa dimainkan mahasiswa dalam pengembangan ekonomi Islam adalah: ${ }^{5}$

1. Actor

Artinya, mahasiswa semestinya menjadi pionir-pionir dalam praktik ekonomi Islam. Misalnya mahasiswa hanya menjual dan membeli barang dan jasa yang halal saja. Mengelola keuangan tanpa riba.

2. Educator

Sebagai kelompok masyarakat terdidik, mahasiswa secara relative lebih cepat memahami dan memiliki akses ke khasanah wacana ekonomi Islam ketimbang kelompok masyarakat lain.

3. Motivator

Pengkajian dan praktik ekonomi Islam di tengah system kapitalis bukanlah tindakan yang popular, terasa asing dan mudah menimbulkan rasa putus asa mengingat nature dari masyarakat memang tidaklah kompatibel dengan ekonomi Islam.

4. Akselerator

Mahasiswa harus menyadari bahwa sebesar apapun praktik dan setinggi apapun kesadaran masyarakat tentang ekonomi Islam di tengah system sekuler tetaplah belum merupakan wajah sesungguhnya dari keadaan yang sebenarnya bila ekonomi Islam diterapkan secara keseluruhan.

${ }^{5}$ Akhmad Mujahidin, Ekonomi Islam 2, Cet. I, (Pekanbaru: Al-Mujtahadah Press, 2010), Hal. 155-156. 
Melihat status mahasiswa UIN Suska Riau yang banyak mempelajari ilmu agama, fiqh dan muamalah, terutama mahasiswa Fakultas Syari'ah dan Hukum, idealnya mereka yang mempelajari agama mengetahui konsep syari'ah sehingga mereka memahami kesesuaian konsep syari'ah yang ada pada bank BRI Syari'ah. Sehingga mereka yang sudah paham dengan konsep syariah dengan bijak akan menggunkana jasa bank syari'ah. Namun pada kenyataannya masih banyak ditemui mahasiswa yang juga bertransaksi dengan bank-bank konvensional lainnya.

Menurut Wiwiek Rabiatul Adadwiyah, salah satu factor yang cukup penting dalam mengkaji pengembangan Bank Syari'ah adalah melalui pengetahuan masyarakat terhadap keberadaan Bank Syari'ah. Dari hasil penelitiannya diketahui pengetahuan konsumen terhadap Bank Syari'ah masih terbatas, sebagian besar responden hanya mengetahui tentang riba dan syari'ah. Sedangkan istilah-istilah seperti ijarah, mudharabah, musyarakah, dan murabahah masih belum diketahui dan dimengerti oleh konsumen. Sebagian besar konsumen sangat setuju apabila Bank Syari'ah membuka cabang di seluruh Indonesia, ${ }^{6}$ maka tulisan ini terfokus dengan pembahasan; pemahaman mahasiswa Fakultas Syari'ah dan Hukum UIN Suska Riau terhadap kesesuaian konsep syari'ah pada Bank BRI Syari'ah. Dimana tujuan dari pembahasan dalam tulisan ini adalah untuk memberikan pengetahuan secara khusus tentang pemahaman mahasiswa Fakultas Syari'ah dan Hukum UIN Suska Riau terhadap kesesuaian konsep syari'ah pada Bank BRI Syari'ah.

\section{Tinjauan Pustaka}

1. Pemahaman

Dalam kamus besar Bahasa Indonesia pemahaman berasal dari kata dasar 'paham' yang artinya pengetahuan banyak, pendapat pikiran, pandangan, pandai dan mengerti benar tentang suatu hal. Sedangkan pemahaman merupakan proses, cara, perbuatan memahami atau memahamkan. ${ }^{7}$

Pemahaman merupakan kemampuan untuk menerangkan dan menginterprestasikan sesuatu, ini berarti bahwa seseorang yang telah memahami sesuatu atau telah memperoleh pemahaman akan mampu menerangkan atau menjelaskan kembali apa yang telah ia terima. Selain itu, bagi mereka yang telah memahami tersebut, maka ia mampu

${ }^{6}$ Wiwiek Rabiatul Adawiyah, Pertimbangan, Pengetahuan, dan Sikap Konsumen Individu Terhadap Bank Syariah, 2010. Dalam Jurnal Ekonomi Pembangunan Volume 11 Nomor 2.

${ }^{7}$ Departemen Pendidikan Nasional, Kamus Besar Bahasa Indonesia, (Jakarta: Balai Pustaka, 2005) cet III, Hal. 811. 
memberikan interprestasi atau menafsirkan secara luas sesuai dengan keadaan yang ada disekitarnya, ia mampu menghubungkan dengan kondisi yang ada saat ini dan yang akan datang. ${ }^{8}$

Pemahaman tersebut dimaksudkan untuk kepentingan pemberian bantuan bagi pengembangan potensi yang ada padanya dan penyelesaian masalah-masalah yang dihadapinya. Manusia dalam kenyataannya berbeda-beda dalam kemampuan berpikirnya, karakter kepribadiannya, dan tingkah lakunya. Semuanya itu bisa ditaksir atau diukur dengan bermacam-macam cara. ${ }^{9}$

Berdasarkan pengertian di atas, dapat dipahami bahwa pemahaman mahasiswa adalah suatu langkah atau proses dalam mencapai suatu tujuan bagi mahasiswa. Dalam mencapai suatu tujuan perlu adanya pengetahuan yang mampu menciptakan adanya cara pandang ataupun pemikiran yang benar akan suatu hal.

Memahami pengetahuan konsumen sangat penting bagi pemasar. Karena apa yang dibeli, berapa banyak yang dibeli, dimana membeli dan kapan membeli akan tergantung kepada pengetahuan konsumen mengenai hal-hal tersebut. Pengetahuan konsumen akan mempengaruhi keputusan atau minat pembelian. Ketika konsumen memiliki pengetahuan yang lebih banyak, maka ia akan lebih baik dalam mengambil keputusan, ia akan lebih efisien dan lebih tepat dalam mengolah informasi dan mampu merecall informasi dengan lebih baik. ${ }^{10}$

Pengetahuan konsumen adalah semua informasi yang dimiliki konsumen mengenai berbagai macam produkdan jasa, serta pengetahuan lainnya yang terkait dengan produk dan jasa tersebut dan informasi yang berhubungan dengan fungsinya sebagai konsumen. ${ }^{11}$ Proses pengolahan informasi, pembentukan pengetahuan dan proses belajar akan sangat menentukan apakah konsumen berminat terhadap suatu produk sebelum ia memutuskan untuk membeli atau mengkonsumsinya.

Pengetahuan konsumen yang dimaksud peneliti disini adalah pengetahuan konsumen tentang Bank Syari'ah. Sehingga dari uraian tersebut diatas, dapat disimpulkan bahwa pengetahuan konsumen tentang Bank Syari'ah adalah semua informasi yang dimiliki oleh

${ }^{8}$ Ahmad Susanto, Teori Belajar dan Pembelajaran Di Sekolah Dasar, (Jakarta: Kencana Prenada Media Group, 2013), Hal. 7.

${ }^{9}$ Susilo Rahardjo, Pemahaman Individu: Teknik Nontes, (Jakarta: Kancana Prenada Media Group, 2013), Hal. 2.

${ }^{10}$ Ujang Sumarwan, Perilaku Konsumen: Teori dan Penerapannya Dalam Pemasaran, (Bogor: Ghalia Indonesia, 2002), Hal. 119.

\footnotetext{
${ }^{11}$ Ibid., Hal. 120.

${ }^{12}$ Ibid., Hal. 135.
} 
konsumen mengenai Bank Syariah, baik definisi Bank Syari'ah, prinsipprinsip Bank Syari'ah, berbagai macam produk maupun jasa Bank Syari'ah.

Proses pengolahan informasi, pembentukan pengetahuan dan proses belajar akan sangat menentukan apakah konsumen berminat terhadap suatu produk sebelum ia memutuskan untuk membeli atau mengkonsumsinya. ${ }^{13}$ Kebanyakan masyarakat memang sudah tahu apa itu Bank Syari'ah, tetapi mereka tidak tahu produk-produk yang ditawarkan Bank Syariah, sehingga masyarakat yang tidak tahu produkproduk bank syariah tentunya tidak akan berminat untuk menggunakan jasa Bank Syari'ah karena mereka menganggap bahwa fasilitas penunjang yang diberikan masih kalah dengan fasilitas yang ditawarkan oleh bank konvensional, kecuali orang yang mempunyai kenginan kuat menabung pada bank syariah dikarenakan menghindari unsur riba.

Menurut Wiwiek Rabiatul Adawiyah meskipun mayoritas penduduk Indonesia adalah Muslim, banyak yang tidak mengetahui sama sekali mengenai produk-produk dan jasa yang Bank Syari'ahditawarkan oleh, hal tersebut membuat calon nasabah merasa kurang berminat menggunakan jasa Bank Syari'ah. Sebaliknya, minat mengunakan jasa Bank Syari'ah akan timbul jika pengetahuan mengenai produk dan jasa perbankan tersebut sudah diketahui dengan baik karena pelanggan dapat menggunakan dan memanfaatkan fasilitas dari bank tersebut. ${ }^{14}$

Berkaitan dengan bank syariah, menurut MIFC (Malaysia International Islamic Financial Center) menyebutkan bahwa bank syariah perlu menerapkan kepatuhan syariah agar masyarakat dapat membedakan antara bank syariah dan bank konvensional. Selain itu, penerapan kepatuhan syariah menjadi penting dikarenakan meningkatnya kesadaran masyarakat bahwa produk berbasis syariah tidak hanya menawarkan alternatif yang lebih aman, tetapi juga memiliki etika bisnis yang adil, bersih dan transparan sehingga NonMuslim pun ikut tertarik dan sadar pentingnya entitas atau bank yang berbasis syariah.

Sehingga untuk menjamin teraplikasinya prinsip-prinsip syariah di lembaga perbankan, maka elemen yang memiliki otoritas dan wewenang dalam melakukan pengawasan terhadap kepatuhan syariah adalah Dewan Pengawas Syariah (DPS). Peran yang dilakukan oleh

\section{${ }^{13}$ Ibid.}

14 Wiwiek Rabiatul Adawiyah, Pertimbangan, Pengetahuan, dan Sikap Konsumen Individu Terhadap Bank Syariah, 2010. Dalam Jurnal Ekonomi Pembangunan Volume 11 Nomor 2. 
Dewan Pengawas Syariah (DPS) adalah untuk memastikan bahwa operasional institusi syariah, dalam hal ini bank syariah memenuhi prinsip syariah. Sebelumnya, hal ini telah didukung dengan Surat Keputusan Dewan Pimpinan MUI tentang Pembentukan Dewan Syariah Nasional (DSN) No. Kep-754/MUI/II/1999 yang menjelaskan bahwa DPS melakukan pengawasan secara periodik pada lembaga keuangan syariah yang berada di bawah pengawasannya, DPS berkewajiban mengajukan usul-usul pengembangan lembaga keuangan syariah kepada pimpinan lembaga yang bersangkutan dan kepada DSN, DPS melaporkan perkembangan produk dan operasional lembaga keuangan syariah yang diawasinya kepada DSN sekurang-kurangnya dua kali dalam satu anggaran dan DPS merumuskan permasalahanpermasalahan yang memerlukan pengawasan DSN.

Oleh karena itu, penerapan kepatuhan syariah juga harus diperankan oleh seluruh elemen organisasi kepatuhan dalam lembaga, yang terdiri dari Direktur yang membawahi fungsi kepatuhan di Bank Islam, Kepala unit kepatuhan dan satuan kerja kepatuhan untuk mengelola risiko kepatuhan. Kepatuhan merupakan tanggung jawab bersama yang dilaksanakan oleh seluruh karyawan bank, dari atasan sampai bawahan (top-down). Dengan demikian, adanya tanggung jawab DPS dan keaktifan dari berbagai elemen perbankan syariah dalam penerapan sharia complianceberdasarkan UU, PBI, maupun fatwa DSNMUI, maka hal ini mengindikasikan bahwa penerapan sharia complince pada bank syariah dapat dilihat dari pemaparan laporan keuangan, produk, pelayanan, tata kelolaan, kepedulian lingkungan maupun kegiatan operasional lainnya.

2. Konsep syari'ah pada bank syari'ah

Prinsip-prinsip Dasar Syari'ah

Bank syariah adalah bank yang beroperasi sesuai dengan Prinsip-Prinsip Syariah. ${ }^{15}$ Implementasi prinsip syariah inilah yang menjadi pembeda utama dengan bank konvensional. Pada intinya prinsip syariah tersebut mengacu kepada syariah Islam yang berpedoman utama kepada Al Quran dan Hadist. Islam sebagai agama merupakan konsep yang mengatur kehidupan manusia secara komprehensif dan universal baik dalam hubungan dengan Sang Pencipta (HabluminAllah) maupun dalam hubungan sesama manusia (Hablumminannas).

Ada tiga pilar pokok dalam ajaran Islam yaitu :

${ }^{15}$ Kasmir, Manajemen Perbankan, (Jakarta: PT Raja Grafindo Persada, 2010), Hal. 11. 
Aqidah : komponen ajaran Islam yang mengatur tentang keyakinan atas keberadaan dan kekuasaan Allah sehingga harus menjadi keimanan seorang muslim manakala melakukan berbagai aktivitas dimuka bumi semata-mata untuk mendapatkan keridlaan Allah sebagai khalifah yang mendapat amanah dari Allah.

Syariah : komponen ajaran Islam yang mengatur tentang kehidupan seorang muslim baik dalam bidang ibadah (habluminAllah) maupun dalam bidang muamalah (hablumminannas) yang merupakan aktualisasi dari akidah yang menjadi keyakinannya. Sedangkan muamalah sendiri meliputi berbagai bidang kehidupan antara lain yang menyangkut ekonomi atau harta dan perniagaan disebut muamalah maliyah

Akhlaq : landasan perilaku dan kepribadian yang akan mencirikan dirinya sebagai seorang muslim yang taat berdasarkan syariah dan aqidah yang menjadi pedoman hidupnya sehingga disebut memiliki akhlaqul karimah sebagaimana hadis nabi yang menyatakan "Tidaklah sekiranya Aku diutus kecuali untuk menjadikan akhlaqul karimah.

Kegiatan bank syariah merupakan implementasi dari prinsip ekonomi Islam dengan karakteristik, antara lain, sebagai berikut: ${ }^{16}$

1. Pelarangan riba dalam berbagai bentuknya;

2.Tidak mengenal konsep time-value of money tetapi menerapkan economic value of time;

3. Konsep uang sebagai alat tukar bukan sebagai komoditas;

4. Tidak diperkenankan melakukan kegiatan yang bersifat spekulatif;

5. Tidak diperkenankan menggunakan dua harga untuk satu barang;

6. Tidak diperkenankan dua transaksi dalam satu akad.

Bank syariah tidak menggunakan bunga sebagai alat untuk memperoleh pendapatan maupun membebankan bunga atas penggunaan dana dan pinjaman karena bunga merupakan riba yang diharamkan. Berbeda dengan bank non-syariah, bank syariah tidak membedakan secara tegas antara sektor moneter dan sektor riil sehingga dalam kegiatan usahanya dapat melakukan transaksi-transaksi sektor riil, seperti jual beli dan sewa menyewa. Di samping itu, bank syariah juga dapat menjalankan kegiatan usaha untuk memperoleh imbalan atas jasa perbankan lain yang tidak bertentangan dengan prinsip syariah. Suatu transaksi sesuai dengan prinsip syariah apabila telah memenuhi seluruh syarat berikut ini: ${ }^{17}$ Transaksi tidak mengandung unsur kedzaliman dan bukan termasuk riba,

16 Muhammad, Manajemen Keuangan Syariah: Analisis Fiqh dan Keuangan, (Yogyakarta: UPP STIM YKPN, 2014), Hal. 229.

${ }^{17}$ Ibid., Hal. 230. 
tidak membahayakan pihak sendiri atau pihak lain, tidak ada unsur penipuan (Tadlis), perjudian (Maisyir), tagrir (Gharar), rekayasa pasar dalam Supply (Ikhtikar), rekayasa pasar dalam Demand (Bai'Najasy), suapmenyuap (Risywah) dan Tidak mengandung materi-materi yang diharamkan.

\section{Kesimpulan}

Pemahaman mahasiswa adalah proses dalam mencapai suatu tujuan bagi mahasiswa. Dalam mencapai suatu tujuan perlu adanya pengetahuan yang mampu menciptakan adanya cara pandang ataupun pemikiran yang benar akan suatu hal. Pengetahuan konsumen adalah semua informasi yang dimiliki konsumen mengenai berbagai macam produkdan jasa, serta pengetahuan lainnya yang terkait dengan produk dan jasa tersebut dan informasi yang berhubungan dengan fungsinya sebagai konsumen.

Pengetahuan dalam penelitian ini adalah pengetahuan mahasiswa yang objeknya Bank Syari'ah. Berarti pengetahuan tentang Bank Syari'ah adalah segala sesuatu yang diketahui oleh mahasiswa tentang Bank Syari'ah baik mengenai definisi Bank Syari'ah, prinsip-prinsip Bank Syari'ah, produk-produk Bank Syari'ah dan jasa Bank Syari'ah.

Variable pengetahuan diukur melalui angket dengan 4 indikator dan 20 pernyataan, yaitu pengetahuan definisi Bank Syari'ah, pengetahuan prinsip-prinsip Bank Syari'ah, pengetahuan produk-produk Bank Syari'ah dan pengetahuan jasa Bank Syari'ah.

Hasil penelitian menunjukkan rata-rata pengetahuan mahasiswa

Fakultas Syari'ah dan Hukum UIN Suska Riau tentang definisi Bank Syari'ah, prinsip-prinsip Bank Syari'ah, produk-produk Bank Syari'ah, jasa yang ditawarkan oleh Bank Syari'ah tinggi. Artinya mahasiswa sudah mengetahui bahwa Bank BRI Syari'ah adalah Bank yang beroperasi berdasarkan prinsip syari'ah. Prinsip-prinsip Bank Syari'ah pada dasarnya terdiri dari prinsip simpanan, bagi hasil, jual beli, sewa dan jasa. Produkproduk Bank Syari'ah pada dasarnya terdiri dari produk yang berdasarkan prinsip titipan, bagi hasil, jual beli, sewa dan pelengkap. Serta jasa yang ditawarkan oleh Bank Syari'ah pada dasarnya terdiri dari transfer, kliring, inkaso, rahn, LC, bank garansi syari'ah, sharf.

Dalam dunia perbankan yang semakin berkembang, pengetahuan nasabah dapat diperoleh dari berbagai sumber, seperti media informasi cetak maupun elektronik. Terutama bagi mahasiswa Fakultas Syari'ah dan Hukum UIN Suska Riau pemahaman tentang konsep syariah pada Bank Syari'ah dapat diperoleh dari pelajaran yang diterima di bangku kuliah sebagai mahasiswa Fakultas Syari'ah dan Hukum. Sehingga Berdasarkan 
analisis yang telah dilakukan dapat disimpulkan bahwa mayoritas mahasiswa Fakultas Syari'ah dan Hukum UIN Suska Riau sudah memahami kesesuaian konsep syari'ah pada Bank Syari'ah.

\section{Daftar Pustaka}

Ahmad Ifham Sholihin, 2010, Buku Pintar Ekonomi Syariah, Jakarta: PT. Gramedia Pustaka Utama.

Ahmad Rodoni dan Abdul Hamid, 2008, Lembaga Keuangan Syariah, Cet. I, Jakarta: Zikrul Hakim.

Ahmad Susanto, 2013, Teori Belajar dan Pembelajaran Di Sekolah Dasar, Jakarta: Kencana Prenada Media Group.

Akhmad Mujahidin, 2010, Ekonomi Islam 2, Cet. I, Pekanbaru: Al-Mujtahadah. 2014, Ekonomi Islam 2 (Pasar, Perdagangan, Manajemen, Produksi, Konsumsi, Institusi Keuangan, dan Kontribusi), Ed. 1, Cet. I, Pekanbaru: Al-Mujtahadah Press.

Ali Hasan, SE. MM, 2010, Marketing Bank Syariah, Cet. 1, Bogor: Ghalia Indonesia.

Andi Mappiare, 1997, Psikologi Remaja, Surabaya: Usaha Nasional.

Andri Soemitra, 2009, Bank \&Lembaga Keuangan Syariah, Jakarta: Kencana Prenada Media Group.

Ascarya, 2007, Akad dan Produk Syariah, Jakarta: PT. Raja Grafindo Persada.

Baker Ahmad Alserhan, 2011, The Principles of Islamic Marketing, England: Gower Publishing Limited.

Bank Indonesia, "Statistik Perbankan Indonesia", dalam www.bi.go.id di akses 25 Agustus 2015.

Buchari Alma, 2014, Manajemen Pemasarandan Pemasaran Jasa, Bandung: Alfabeta.

C. Trihendradi, 2012, Step by Step SPSS 20 Analisis Data Statistik. Ed. 1, Yogyakarta: ANDI.

Dahlan Siamat, 2005, Manajemen Lembaga Keuangan Kebijakan Moneter dan Perbankan, Ed. 5, Jakarta: Lembaga Penerbit Fakultas Ekonomi Universitas Indonesia.

Danang Sunyoto, 2014, Praktik Riset Perilaku Konsumen (Teori Kuesioner, Alat, dan Analisis Data), Yogyakarta: CAPS.

Departemen Pendidikan Nasional, 2005, Kamus Bahasa Indonesia, Jakarta: Balai Pustaka.

Didin Hafidhuddin dan Hendri Tanjung, 2003, Manajemen Syariah Dalam Praktik, Cet. 1, Jakarta: Gema Insani Press..

Duwi Priyanto, Cara Kilat Belajar Analisis Data dengan SPSS 20, Ed.1, Yogyakarta: ANDI. 
Eman Sulaiman, 2007, Marketing Muhammad Strategi Andaldan Jitu Praktik Bisnis Nabi Muhammad Saw, Bandung: PT. Karya Kita.

Engel, J. F. Blackwell, R.D, Miniard, P.W, 1995, Perilaku Konsumen Jilid 2, Jakarta: Binarupa Aksara.

Erna Ferrinadewi, 2008, Merk \& Psikologi Konsumen, Ed. I, Cet. I, Yogyakarta: Graha Ilmu.

Husen Umar, 2003, Metode Riset Bisnis, Jakarta: PT. Gramedia Pustaka Utama. I Made Wirartha, 2006, Pedoman Penulisan Usulan Penelitian, Skripsi, dan Tesis, Yogyakarta: ANDI.

Iqbal Hasan, 2005, Pokok-pokok Materi Statistik, Ed. Ke-2, Cet. ke-3. Jakarta: Bumi Aksara.

Irawan, 2002, 10 Prinsip Kepuasan Pelanggan. Jakarta :Elex Media Komputindo.

Jonathan Sarwono, 2006, Metode Riset Skripsi Pendekatan Kuantitatif Menggunakan Prosedur SPSS, Jakarta: PT. Gramedia.

, 2008, Metodologi Penelitian Ekonomi Islam Pendekatan Kuantitatif, Jakarta: Rajawali Pers.

Muhammad, 2014, Manajemen Keuangan Syariah: Analisis Fiqh dan Keuangan, Yogyakarta: UPP STIM YKPN.

Muhammad Muflih, 2006, Perilaku Konsumen Dalam Perspektif Ilmu Ekonomi Islam, Ed. 1, Jakarta: PT. Raja Grafindo Persada.

Muhammad Syafi'i Antonio, 2001, Bank Syariah: Dari Teori ke Praktik, Jakarta: Gema Insani Press.

Ujang Sumarwan, 2002, Perilaku Konsumen: Teori dan Penerapannya Dalam Pemasaran, Bogor: Ghalia Indonesia.

Kasmir, 2010, Manajemen Perbankan, Jakarta: PT Raja Grafindo Persada.

Kautsar Audytra Muhammad, Pengaruh Pengetahuan Warga Tentang Perbankan Syariah Terhadap Minat Memilih Produk Bank Muamalat (Studi Kasus Santri Pondok Pesantren Darunnajah), 2014, UIN Syarif Hidayatullah Jakarta.

Software Al-Qur'an Digital.

Susilo Rahardjo, 2013, Pemahaman Individu: Teknik Nontes, Jakarta: Kancana Prenada Media Group.

Toni Prasetyo Utomo, Analisis Faktor-Faktor Yang Mempengaruhi Keputusan Nasabah Dalam Memilih Jasa Perbankan Syariah (Studi Pada Bank Syariah Mandiri, Kantor Cabang Malang), 2014, Universitas Brawijaya Malang. 
Kridawati Sadhana, Sosialisasi dan Persepsi Bank Syariah (Kajian Kebijakan Enkulturasi Nilai-Nilai Bank Syariah Dalam Masyarakat), 2012, Universitas Merdeka Malang.

Mehrdad Estiri, Farshid Hosseini dan Hamidreza Yazdani, International Journ : Determinants of customer satisfaction in Islamic Banking: Evidence frim Iran, 2011.

Wiwiek Rabiatul Adawiyah, Pertimbangan, Pengetahuan, dan Sikap Konsumen Individu Terhadap Bank Syariah, 2010. Jurnal Ekonomi Pembangunan Volume 11 Nomor 2.

www.ojk.go.id

http://library.walisongo.ac.id/digilib/gdl.php?mod=browse\&op=read\&id=jtptiai n-gdl-rifaatulma-4923 